\title{
Required flows for aquatic ecosystems in Ma River, Vietnam
}

\author{
Luong Ngoc Chung ${ }^{1}$, Nguyen Thi Kim Cuc ${ }^{2}$, Trieu Anh $\mathrm{Ngoc}^{3}$, Nguyen Thanh $\mathrm{Nam}^{4}$, \\ Le Viet Son $^{5}$, Tran Viet $\mathrm{On}^{6}$
}

${ }^{1}$ Luong Ngoc Chung, Institute of Water Resources Planning, 162A Tran Quang Khai, Hoan Kiem, Hanoi, Vietnam, Email: ngocchung.iwrp@gmail.com

${ }^{2}$ Nguyen Thi Kim Cuc, Thuy Loi University, 175, Tay Son, Dong Da, Ha Noi, Vietnam, Email: Nguyencuc@tlu.edu.vn

${ }^{3}$ Trieu Anh Ngoc, Thuy Loi University - Second Base, No. 2, Truong Sa, Ward 17, Binh Thanh Dis., HCMC, Email: ngocta@tlu.edu.vn

${ }^{4}$ Nguyen Thanh Nam, VNU University of Science, Hanoi. 334 Nguyen Trai Street, Thanh Xuan District, Hanoi, Vietnam.

Email: nguyenthanhnam@hus.edu.vn

${ }^{6}$ Le Viet Son, Institute of Water Resources Planning, 162A Tran Quang Khai, Hoan Kiem, Hanoi, Vietnam,

Email: levietson2211@gmail.com

${ }^{7}$ Tran Viet On: Thuy Loi University, 175, Tay Son, Dong Da, Ha Noi, Vietnam,

Email: tranvieton@tlu.edu.vn

\begin{abstract}
Ecological flow requirements for the Ma River in dry season were assessed in three reaches of Ma-Buoi, Ma - Len and Ma - Chu. 5 indictor fish species was chosen based on biodiversity survey and roles of those species in aquatic ecosystem as well as local communities. Biological and hydrological data (dry season of 20162017) and 35 year recorded hydrological data were collected and analyzed as input data for a physical habitat model River HYdraulic and HABitat SImulation Model RHYHABSIM. Model results shown that the optimal flows of the reaches were very much higher compare with the minimum annual low flow - MALF. In this study, MALF $F_{\text {day }}$ were applied to calculate the recommended minimum flows of the three reaches. The recommended required minimum flows for Ma - Buoi, Ma - Len and Ma - Chu reaches were $51 \mathrm{~m}^{3} / \mathrm{s}, 49 \mathrm{~m}^{3} / \mathrm{s}$ and $61 \mathrm{~m}^{3} / \mathrm{s}$, respectively. It must be stressed that this study only assessed whether or not there is enough habitat available for the river to sustain a healthy ecosystem.
\end{abstract}

Keywords - Ma River, Minimum Annual Low Flow MALF, Required flows, River HYdraulic and HABitat SImulation Model - RHYHABSIM, Weighted Useable Area-WUA.

\section{INTRODUCTION}

Flow management, in its basic sense, is the allocation of the resources, water, for specific uses and purposes. The different uses for an individual flow could include domestic used water, irrigation, fisheries, recreation, carrier of treated waste-water, and the maintenance of the natural/native biodiversity etc. At any point in time, the water quantity in a flow is affected by natural factors such as precipitation and geology, as well anthropogenic influences including the physical alteration of the stream, river, dams/weirs, and surface and groundwater abstraction [1].

Water abstraction plays an important part in most surface water systems, especially, the water that is present in a flow even during extended dry periods. Over exploitation of flow's water resources can significantly reduce a stream's base flow to the point where once permanent streams become ephemeral. This change can have severe consequences for the native flora and fauna of the flow (i.e. [2], [3], [4]).

In order to manage the freshwater resources, both an inventory of the water resource available and an assessment of the ecology of the natural (unaltered) freshwater ecosystem need to be undertaken. Habitat models such as habitat hydraulic models are one of the tools available to evaluate how changing flow regimes will affect the physical habitat for the biological communities [5]. These models combine the hydrological and biological variables in a system, simulating how available habitat for a particular species will change with differing hydrological responses to resource utilization [6], [7]. RHYHABSIM (short for River HYdraulic and HABitat SImulation Model) was developed by Ian Jewett in the 1980s and is continuingly being improved, intended for use by water managers [5], [8]. RHYHABSIM is able to model habitat responses to changing hydrological conditions, and has been identified as a management tool for assessing current ecosystem condition. 
Hydraulic-habitat models marry water depth and velocity predictions made by a hydraulic model with fish frequency-or density-based habitat suitability criteria (or curves) (HSC) for these hydraulic, and other physical, habitat variables (e.g., substrate) to predict weighted useable area (WUA; more correctly termed the area weighted suitability) [9], [10].

Habitat models, such as RHYHABSIM, attempt to quantify the flow required to maintain a healthy ecosystem, thus providing stream/river managers with important information from which to base their water management decisions (such as water abstraction) upon.

This paper looks at the application of RHYHABSIM as a tool to aid the management of freshwater ecosystems. Applying on a case study of Ma River, Vietnam, the model is used to predict the flows needed to provide the necessary habitat to sustain naturally recruiting populations of local fish species in dry season. The application of the model is evaluated with regard to its usefulness from a resource manager's perspective.

\section{STUDY SITE AND METHODOLOGY}

\subsection{Study site}

The Ma River is a river in Asia, originating in northwest of Vietnam. It runs for $400 \mathrm{~km}$ through Vietnam, Laos, and then back through Vietnam, meeting the sea at the Gulf of Tonkin.

The largest tributaries of the Ma River are the Chu River (or the Nam Sam River as it is called in Laos), the Buoi River, and the Cau Chay River. All of them join the Ma River in Thanh Hoa Province in North Central Vietnam. The Ma River creates the Ma River Delta (also called the Thanh Hoa Delta), the third largest in Vietnam. Like the Red River (Song Hong) to the north, it has an irregular regime with maximum flow toward the end of the summer.

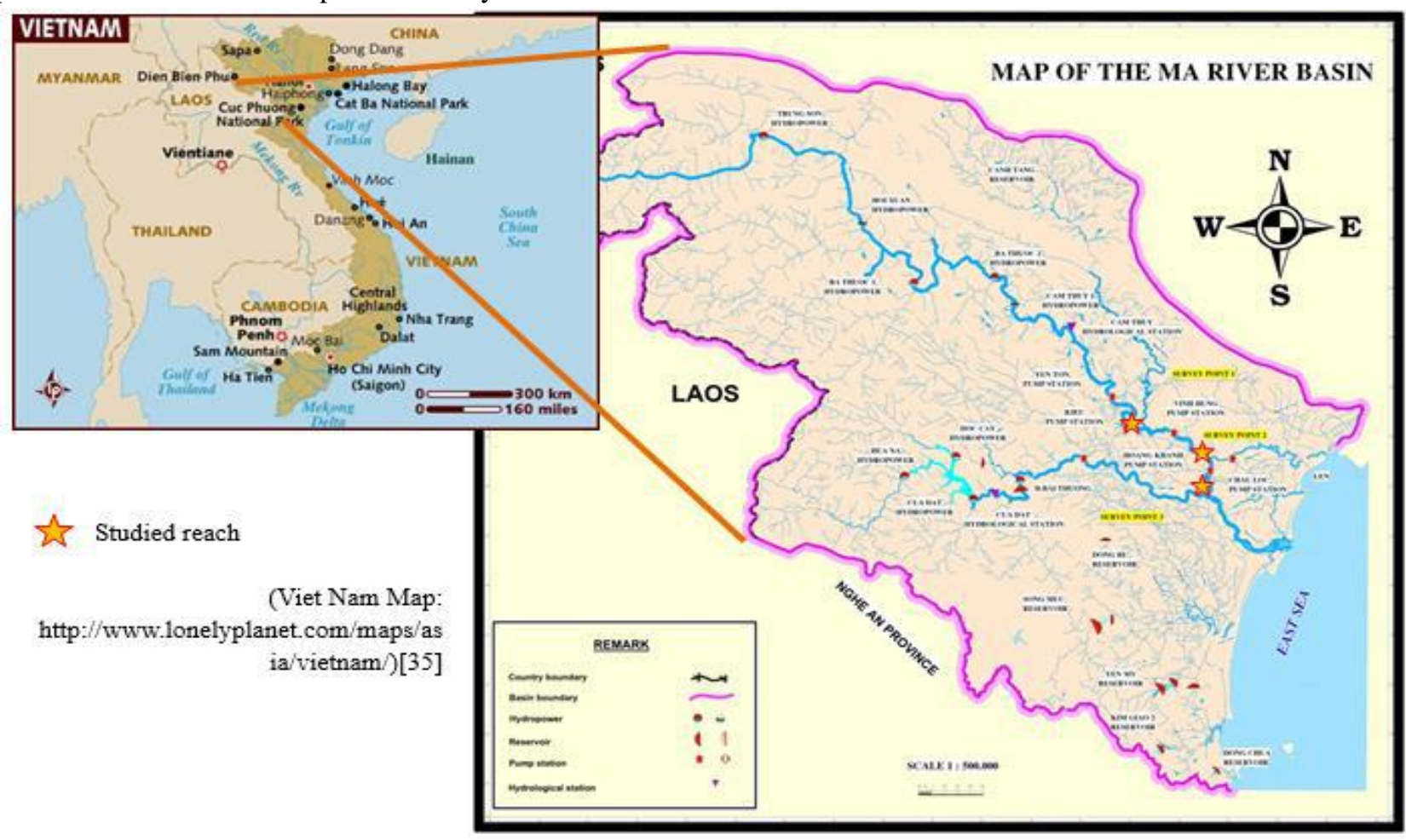

Fig. 1: Map of Ma River Basin

The Ma River delta differs, however, from that of the Red River because of its narrowness and the presence of sandy soil.

The average temperature in the Ma River basin is relatively high throughout the year. The average temperature recorded at the 14 meteorological stations within the Ma River basin varies spatially ranging from 20.9-23. $0^{\circ} \mathrm{C}$, reflecting the topographical characteristics and altitudes of the locations. Annual rainfall is substantial with dominant winds from south and southeast during May to September months.
The river flow varies greatly in time and space. The river flow in cubic meters per second $\left(\mathrm{m}^{3} / \mathrm{s}\right)$ varies quite greatly in Cam Thuy. The average discharge in April $\left(111 \mathrm{~m}^{3} / \mathrm{s}\right)$ is only one-third of the annual discharge $\left(334 \mathrm{~m}^{3} / \mathrm{s}\right)$ and one-seventh of the highest average discharge (in August). Data show that the highest discharges monitored at Cua Dai, Xuan Khanh and Cam Thuy are $442 \mathrm{~m}^{3} / \mathrm{s}$ and 1,713 $\mathrm{m}^{3} / \mathrm{s}$, respectively, and 258 times higher than the lowest discharges at the same gauging station.

In the dry season, the runoff is only 4.76 billion $\mathrm{m}^{3}$, making up $26 \%$ of the total annual runoff. The driest period is between February and April, which comprises 
$8 \%$ of the annual flow. March tends to have the lowest flow rates, contributing only $2.4 \%$ of the total [11]. Together with the demand for difference water uses, the requirement water for aquatic ecosystem in Ma River becomes an issue especially in dry season.

There are three reaches with 17 cross sections (4 to 8 cross sections per reach) were set up and investigated in the main flow of Ma River during dry season of 20162017. All the reaches are located in upstream of the distributaries of Ma River, the first one is Buoi River, second one is Len River and the last one is Chu River (Figure 1).

\subsection{RHYHABSIM}

RHYHABSIM uses a combination of a hydraulic simulation model to predict flow conditions, and biological models to quantify how the change in flow impacts available habitat for a number of fish species. Fish habitat predictions are quantified using an index called Weighted Usable Area (WUA), which incorporates the relative quantity and quality of available habitat at a given flow [12], [13]. WUA is expressed as an area of suitable habitat per length of river $\left(\mathrm{m}^{2} / \mathrm{m}\right)$.

The most common use of RHYHABSIM modeling is to provide guidance when setting minimum flow limits for Ma River. This process uses the model results to help inform a minimum flow which balances in stream and out-of-stream uses. This is accomplished primarily by two steps:

- Identifying the point at which habitat loss decreases disproportionally to reduction in flow, known as the inflection point on the habitat $\times$ flow response (WUA) curve;

- Determining a flow-related baseline and assessing habitat relative to that baseline, usually the naturalized mean annual low flow (MALF);

The first step is often used where seasonal flow fluctuations (most notably low flows - dry season) are not the limiting factor in physical habitat for fish species. This is identified where the optimum flow for a given species is less than the mean annual low flow. Using the flow $\times$ WUA curve, the minimum flow is often chosen as the inflection point; where the relationship between flow and habitat is $1: 1$. At flows below this inflection point, a reduction in flow results in a proportionally greater reduction in habitat, thus increasing risk of habitat loss for the management species [14].

\subsection{Stream Survey Methodology}

The objective of the stream survey was to obtain the measurements needed to model the stream parameters that influence fish habitat: stream depth, velocity, discharge and substrate. The three reaches were surveyed according to standard RHYHABSIM protocol and methodology (provided in [15][16]). For this study, each survey site contained 4 to 8 cross-sections, with an even distribution of cross-sections between riffles, runs and pools. The survey took place in two parts - the initial (Feb, 2016), more intense survey, and follow-up visits. The initial visit was used by the model to establish the basic hydraulic parameters for the stream [16]. The follow-up visits (Feb, 2017), conducted at different stream discharge rates, were used to calibrate the model, which was then used to predict how the stream's physical attributes (velocity, width, depth and substrata) change with stream discharge. At the initial survey for each of the 17 cross-sections, the following parameters were measured:

- Stream profile from the top of the stream bank

- the stream profile defined the confines of the stream.

- Flow velocity and discharge rate - velocity is particularly important, as it will vary across the cross-section, influencing the model results.

- The stream stage (water level) at one fixed point in the stream for each cross-section. The stream stage was measured at this point in the follow-up visits.

- The substrata across the profile of the streams. The substrate index is vegetation, mud/silt, sand, gravel, coarse gravel, cobbles, boulders and bedrock, classified as 1-8 respectively [4].

\subsection{Indicator fish species}

In this study, 5 following fish species were used to estimate required water flow for Ma River. 1) Common carp - Cyprinus carpio Linnaeus, 1758 (Cypriniformes: Cyprinidae); 2) Common armorhead catfish Cranoglanis henrici (Vaillant, 1893) (Siluriformes: Cranoglanididae); 3) Greenback mullet - Chelon subviridis (Valenciennes, 1836) (Perciformes: Mugilidae); 4) Dusky sleeper - Eleotris fusca (Forster, 1801) (Perciformes: Eleotridae); and 5) Tank goby Glossogobius giuris (Hamilton, 1822) (Perciformes: Gobiidae).

These 5 species were chosen because of following reasons: different possibility catching along of research areas in Ma River; inhabit in different water column: benthopelagic with common carp, common armorhead catfish and tank goby, demersal with greenback mullet and dusky sleeper; adapt with different optimum current speed: $0.3-0.4 \mathrm{~m} / \mathrm{s}$ with common carp and tank goby, 0.4$0.6 \mathrm{~m} / \mathrm{s}$ with common armorhead catfish and greenback mullet, $0.2-0.3 \mathrm{~m} / \mathrm{s}$ with dusky sleeper; and many different following detail characteristics.

The first species, common carp - Cyprinus carpio, is a very common in freshwater and brackish environment throughout the world with the body size range in $25-36$ $\mathrm{cm}$ as adult. This fish has highly commercial value in fisheries, aquaculture and also in aquarium. Common carp inhabit warm, deep, slow-flowing and still waters such as lowland rivers and large, well vegetated lakes and they 
can adapt with wide variety of conditions but generally favor large water bodies with slow flowing or standing water and soft bottom sediments [17]. Both adults and juveniles feed on a variety of benthic organisms and plant material. They spawn along shores or in backwaters and larvae survive only in very warm water among shallow submerged vegetation. Under tropical conditions, common carp breeds throughout the year but seasonal spawned in temperate waters [18].

The next chosen species is common armorhead catfish Cranoglanis henrici. This species distribute in Thailand, Philippines, Indonesia, China (Hainan island, Guangdong, Guangxi, Yunnan) and Vietnam [19]. They live at bottom and near bottom, preferring moderately and slowly running waters with much sandy and muddy bottom. They usually live in colonies and are found mainly in the downstream of rivers in Northern provinces. C. catfish in general and $C$. henrici in particular are famous for their tasty and nutritious meat. C. henrici is found in all river systems from the North to the South of central Vietnam, but not found in the South [20], [21] with the spawning season from May to July [22].

Greenback mullet, Chelon subviridis, form schools in shallow coastal waters and enters lagoons, estuaries, and fresh water to feed. Juveniles may enter rice fields and mangroves. Greenback mullet feed on small algae, diatoms and benthic detrital material taken in with sand and mud; fry take zooplankton, diatoms, detrital material and inorganic sediment [23]. Spawning occurs at sea with pelagic and non-adhesive eggs [24].

The fourth species, Dusky sleeper - Eleotris fusca, is found in rivers, estuaries and coastal regions throughout the Indo-west Pacific, from the eastern coast of Africa to the Hawaiian Islands where this species spawns during May to December with most proportion from August to November [25], [26]. They occur in the lower reaches of freshwater streams, usually on mud bottoms and feed on crustaceans and small fishes [27]. Dusky sleeper spawns eggs on submerged plants with small leaves, female tends and fans the eggs until hatching and loosely guards the fry for a few days thereafter [28]. Juveniles are found mainly among mangrove roots in the more saline areas of lagoons and estuaries [28].

The last chosen species, Tank goby - Glossogobius giuris, is found mainly in freshwater and estuaries, but also enter the sea; this fish species also occur in canals, ditches and ponds [29]. The species has a marine larval stage, but can breed in fresh water. It has been recorded breeding during the 'dry' season in northern Australia and in summer in South Africa [30] and from March to September in Manchar Lake, Pakistan [31].

\section{RESULTS}

3.1 Biological Data - the Habitat Suitability Curves

The profiles for the thee stream reaches are shown in Table 1 and Figure 2. The upper reach consisted of fast habitats (depth $>0.80 \mathrm{~m}$ and velocity $\geq 0.82 \mathrm{~m} / \mathrm{s}$ ). The lower reach had deep-slow mesohabitat in its part (depth $\sim 2.51 \mathrm{~m}$ and velocity $\sim 0.15 \mathrm{~m} / \mathrm{s}$ ) with area of $475.84 \mathrm{~m}^{2}$ and average width of $189.28 \mathrm{~m}$. The lowest reach and the shallow-fast (depth $\sim 2.81 \mathrm{~m}$ and velocity $\sim 0.16 \mathrm{~m} / \mathrm{s}$ ) with area of $640.52 \mathrm{~m}^{2}$ and average width of $228.12 \mathrm{~m}$.

The Habitat Suitability Curves (HSC) (Figure 3) showed that a depth of $5.0 \mathrm{~m}$ and velocity of around $0.4-0.5 \mathrm{~m} / \mathrm{s}$ are optimum (these are Food producing criteria, Waters 1976). The curves for substrate type indicated that all the five selected species was associated with a wide variety of substrate classes, such as mud/silt, gravel, coarse gravel and sand. The curves for C. henrici, $C$. subviridis, $E$. fusca, G. giuris indicated preference for large boulders and boulders, whereas C. carpio for sand and mud/silt only.

\subsection{Model results}

\section{Ma-Buoi Reach}

The habitat surveys of this reach were carried out at a flow of $80.62 \mathrm{~m}^{3} / \mathrm{s}$, at the survey flow of 76.80-84.97 $\mathrm{m}^{3} / \mathrm{s}$. The average width of this reach was $131.81 \mathrm{~m}$, depth $0.89 \mathrm{~m}$, and velocity $0.90 \mathrm{~m} / \mathrm{s}$. Substrate assessments at all sites were similar, with $>95 \%$ sand and the remaining substrate a mixture of gravel and mud.

Maximum habitat for C. henrici, G. giuris and C. carpio was provided by a flow of $90 \mathrm{~m}^{3} / \mathrm{s}$, and the amount of suitable habitat began to fall when flows fall below 20 $\mathrm{m}^{3} / \mathrm{s}$. Maximum $C$. subviridis and E. fusca habitat was provided by a flow of $80 \mathrm{~m}^{3} / \mathrm{s}$, with a reduction beginning when flows fell below $20 \mathrm{~m}^{3} / \mathrm{s}$ (Figure 4.1, Table 2).

\section{Ma-Len Reach}

The habitat surveys of this reach were carried out at average flow of $74.59 \mathrm{~m}^{3} / \mathrm{s}$, at the survey flow of 70.48 $79.92 \mathrm{~m}^{3} / \mathrm{s}$. The average width of the river was $189.28 \mathrm{~m}$, depth $2.51 \mathrm{~m}$, and velocity $0.15 \mathrm{~m} / \mathrm{s}$. Substrate assessments at all sites were similar, with $73.6 \%$ sand and the remaining substrate a mixture of gravel and mud of 6.9 and 19.5 , respectively.

According to Figure 4.2, Table 2, optimal flow for all the indicator species are very high compare with the previous reach. C. henrici, G. giuris and C. carpio was provided maximum habitat by a flow of more than $80 \mathrm{~m}^{3} / \mathrm{s}$, and the amount of suitable habitat began to fall when flows fall below $30 \mathrm{~m}^{3} / \mathrm{s}$. Maximum C. subviridis and E. fusca habitat was provided by a flow of $100 \mathrm{~m}^{3} / \mathrm{s}$, with a reduction beginning when flows fell below 30 and $\mathrm{m}^{3} / \mathrm{s}$. 
Reach: Ma - Buoi

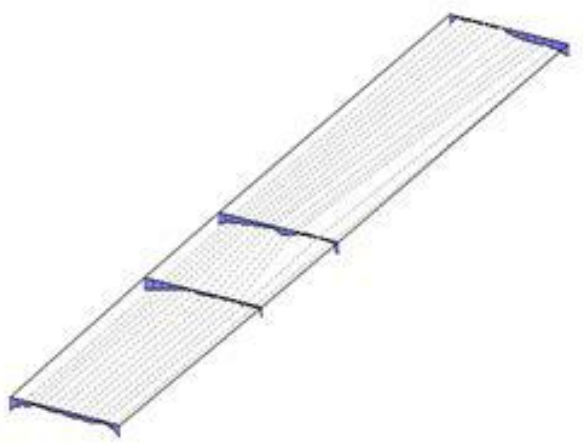

Reach: Ma - Len

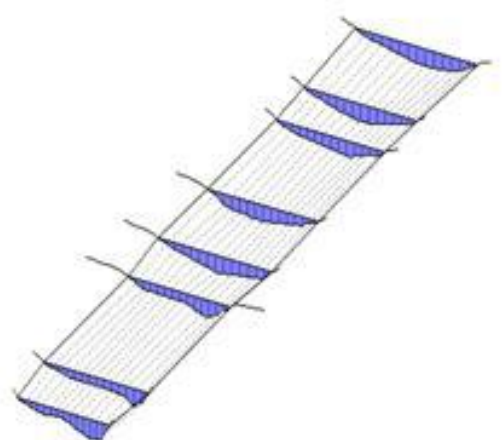

Reach: $\mathrm{Ma}-\mathrm{Chu}$

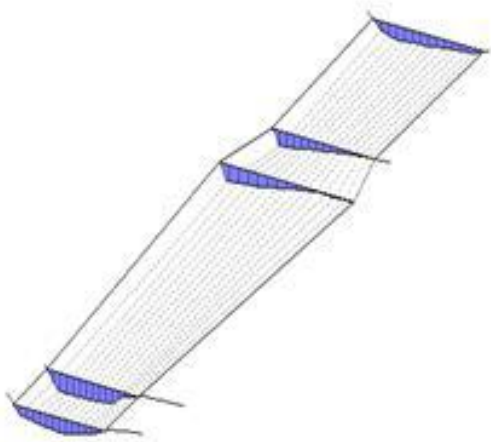

Fig. 2: Isometric view of the cross-sections in the three target reaches of Ma River. Blue color indicates water; solid line indicates the contour of the cross-section.

Table.1: Reach Hydraulic Geometry

\begin{tabular}{lccccc}
\hline Section & $\begin{array}{l}\text { Flow } \\
\left(\mathbf{m}^{\mathbf{3}} / \mathbf{s}\right)\end{array}$ & $\begin{array}{l}\text { Width } \\
(\mathbf{m})\end{array}$ & $\begin{array}{l}\text { Depth } \\
(\mathbf{m})\end{array}$ & $\begin{array}{l}\text { Velocity } \\
(\mathbf{m} / \mathbf{s})\end{array}$ & $\begin{array}{l}\text { Area } \\
\left(\mathbf{m}^{2}\right)\end{array}$ \\
\hline Ma-Buoi & \multicolumn{5}{c}{ Reach length: $\mathbf{1 , 3 0 3 . 2 7} \mathbf{~ m}$} \\
\hline Section1 & 84.97 & 130.30 & 0.81 & 0.94 & 105.94 \\
Section2 & 83.55 & 140.19 & 0.82 & 0.82 & 115.38 \\
Section3 & 76.80 & 111.61 & 0.88 & 0.92 & 98.19 \\
Section4 & 77.16 & 142.21 & 0.98 & 0.89 & 138.59 \\
Reach & $\mathbf{8 0 . 6 2}$ & $\mathbf{1 3 1 . 8 1}$ & $\mathbf{0 . 8 9}$ & $\mathbf{0 . 9 0}$ & $\mathbf{1 1 7 . 6 4}$ \\
\hline Ma-Len & \multicolumn{5}{c}{ Reach length: 1,194.44 $\mathbf{m}$} \\
\hline Section1 & 79.92 & 159.87 & 2.50 & 0.19 & 398.81 \\
Section2 & 78.48 & 181.85 & 2.06 & 0.19 & 374.53 \\
Section3 & 76.52 & 178.05 & 2.35 & 0.17 & 417.95 \\
Section4 & 75.56 & 198.29 & 2.73 & 0.13 & 541.49 \\
Section5 & 71.72 & 192.26 & 2.68 & 0.13 & 515.79 \\
Section6 & 72.25 & 189.37 & 2.44 & 0.15 & 462.84 \\
Section7 & 71.82 & 195.34 & 2.63 & 0.13 & 514.23 \\
Section8 & 70.48 & 211.70 & 2.74 & 0.11 & 579.47 \\
Reach & $\mathbf{7 4 . 5 9}$ & $\mathbf{1 8 9 . 2 8}$ & $\mathbf{2 . 5 1}$ & $\mathbf{0 . 1 5}$ & $\mathbf{4 7 5 . 8 4}$ \\
\hline Ma-Chu & \multicolumn{5}{c}{ Reach length: 1,587.82 $\mathbf{~ m}$} \\
\hline Section1 & 105.84 & 190.47 & 3.34 & 0.16 & 635.61 \\
Section2 & 101.61 & 190.25 & 3.96 & 0.13 & 754.10 \\
Section3 & 107.97 & 281.72 & 2.32 & 0.15 & 654.26 \\
Section4 & 116.51 & 214.63 & 2.13 & 0.22 & 456.71 \\
Section5 & 116.59 & 231.44 & 2.71 & 0.18 & 627.63 \\
Reach & $\mathbf{1 0 9 . 7 0}$ & $\mathbf{2 2 8 . 1 2}$ & $\mathbf{2 . 8 1}$ & $\mathbf{0 . 1 6}$ & $\mathbf{6 4 0 . 5 2}$ \\
\hline & \multicolumn{5}{c}{} \\
\hline
\end{tabular}


A. Cá Chép, Cyprinus carpio (Linnaeus, 1758)
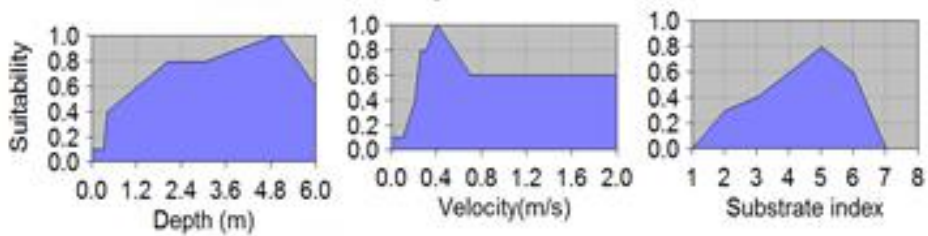

B. Cá Ngạnh thường, Cranoglanis henrici (Vaillant, 1893)
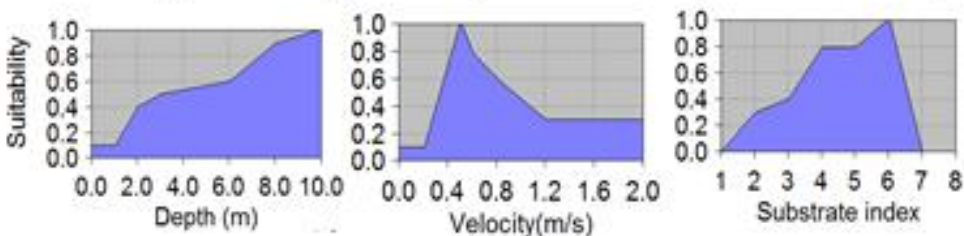

C. Cá Đối đất, Chelon subviridis (Valenciennes, 1836)
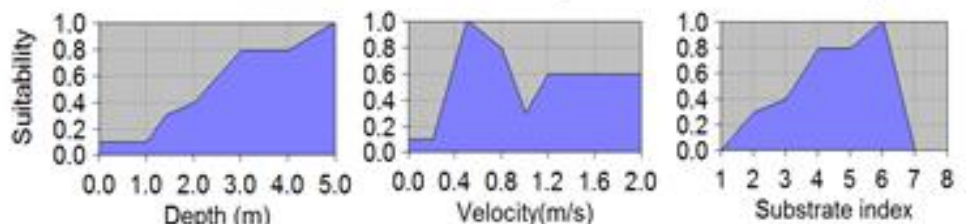

D. Cá Bống mọi, Eleotris fusca (Forster, 1801)
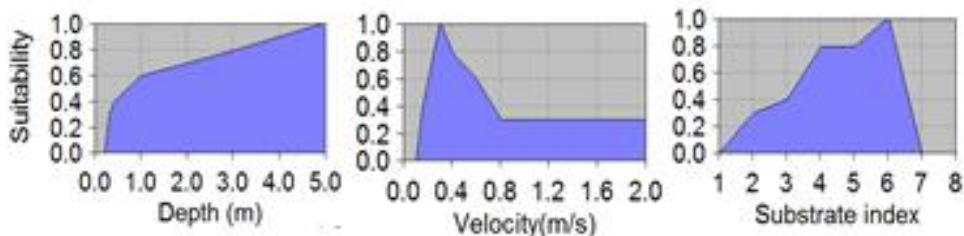

E. Cá Bống cát tối, Glossogobius giuris (Hamilton, 1822)
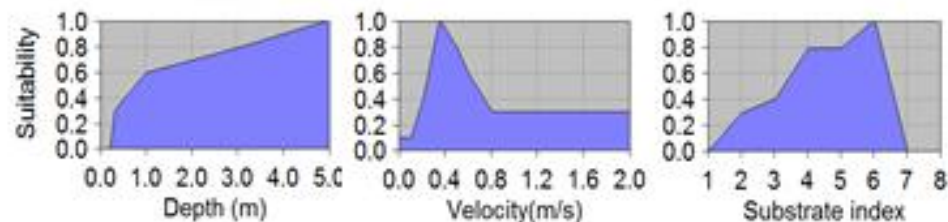

Fig. 3: The biological input to the model in the form of Habitat Simulation Curves.

\section{Ma-Chu Reach}

The habitat surveys of Ma-Chu reach were carried out at an average flow of $109.70 \mathrm{~m}^{3} / \mathrm{s}$, at the survey flow of $101.61-116.59 \mathrm{~m}^{3} / \mathrm{s}$. The average width of the river was $228.12 \mathrm{~m}$, depth $2.81 \mathrm{~m}$, and velocity $0.6 \mathrm{~m} / \mathrm{s}$. Substrate assessments at all sites were similar, with $79.4 \%$ sand and the remaining substrate a mixture of gravel and mud of
3.9 and 16.7, respectively.

Maximum habitat for $C$. henrici, G. giuris and C. carpio was provided by a flow more than $100 \mathrm{~m}^{3} / \mathrm{s}$, and for $C$. subviridis and E. fusca, it was $>130 \mathrm{~m}^{3} / \mathrm{s}$. The amount of suitable habitat began to fall when flows fall below 50 $\mathrm{m}^{3} / \mathrm{s}$ for all C. henrici, C. subviridis, E. fusca, G. giuris and C. carpio (Figure 4.3, Table 2). 
Table.2: Flow requirement for fish species at each reach in Ma River

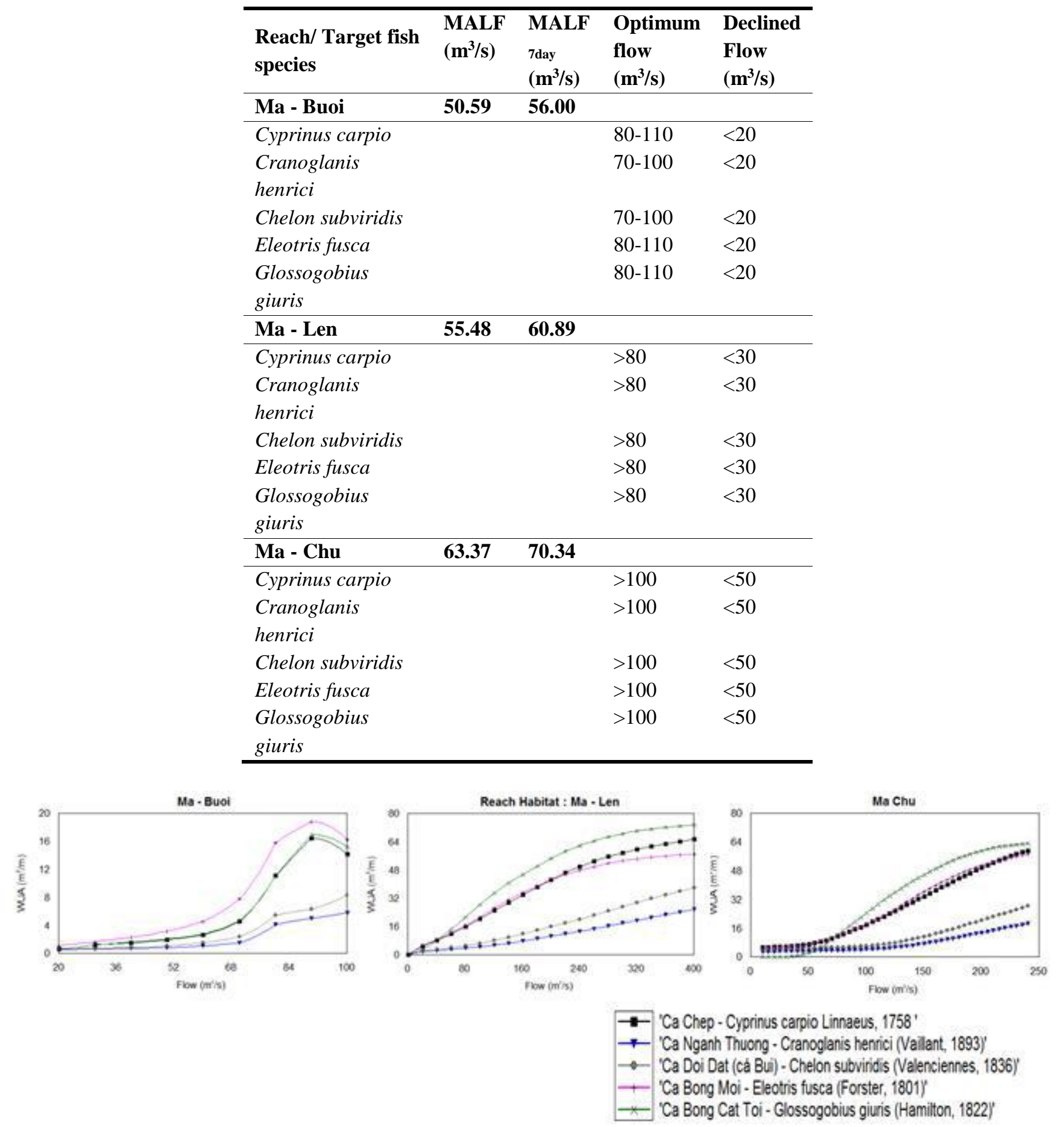

Fig. 4: Fishes' habitats in the three reaches of Ma River 
Table.3: Recommended minimum flows

\begin{tabular}{|c|c|c|c|c|}
\hline Reach & $\begin{array}{l}\text { MALF } \\
\text { 7day } \\
\left(\mathbf{m}^{3} / \mathbf{s}\right)\end{array}$ & $\begin{array}{l}\text { WUA } \\
\left(\mathbf{m}^{2} / \mathbf{m}\right) @ \\
\text { MALF } 7 \\
\text { day }\end{array}$ & $\begin{array}{l}80 \% \text { of WUA } \\
\left(\mathrm{m}^{2} / \mathrm{m}\right) @ \mathrm{MA} \\
\mathrm{LF}_{7 \text { day }}\end{array}$ & $\begin{array}{l}\text { Corresponding } \\
\text { Minimum Flow } \\
\left(\mathrm{m}^{3} / \mathrm{s}\right) \\
\text { (approximate) }\end{array}$ \\
\hline Ma-Buoi & 56.00 & 2.80 & 2.24 & 51.00 \\
\hline Ma - Len & 60.89 & 45.70 & 36.56 & 49.00 \\
\hline $\mathrm{Ma}$ - Chu & 70.34 & 38.80 & 31.04 & 61.00 \\
\hline
\end{tabular}

\section{DISCUSSIONS}

The method of using mean annual low flow (MALF) as an indicator to determine appropriate minimum flows based on RHYHABSIM model outputs have been applied for a number of studies [32]. It states that where maximum habitat is greater than the mean annual low flow (MALF), it is acceptable to set the recommended minimum flow at $80 \%$ of the habitat available at the MALF. This situation often exists in the reach Ma - Buoi in Ma River, where annual summer low flows cannot provide optimum conditions; therefore setting minimum flows at the habitat optimum is unrealistic. The approach described in the Sustainable Low Flow Project recognizes this and uses both habitat data and historical flow data to arrive at minimum flow recommendations that are realistic, conservative, and attainable. It is important to consider natural flow conditions without the influence of abstraction when setting minimum flows.

In several cases, 7-day MALF value was applied instead of 1-day MALF. An analysis of the relationships between the 7-day MALF and the 1-day MALF shows that the ratio ranges from 1.0 to more than 1.7 . More than $80 \%$ of catchments have a ratio of less than 1.2 , and the median ratio is 1.08 [33]. However, low flows is a set the limit to habitat quantity, providing that the duration of low flows is sufficient to engender a biological response [33]. Therefore, in this study, the value of 7-day MALF was used.

The suggested minimum flow rules given in the proposed National Environmental Standard (New Zealand) on ecological flows [34] are:

- For rivers and streams with mean flows less than or equal to $5 \mathrm{~m}^{3} / \mathrm{s}$, a minimum flow of $90 \%$ of the mean annual low flow (MALF).

- For rivers and streams with mean flows greater than 5 $\mathrm{m}^{3} / \mathrm{s}$, a minimum flow of $80 \%$ of MALF.

HSI graphs indicate that the optimum quality of fish habitat occurs at lower flows than optimum habitat quantity (WUA). It is recommended that WUA be the primary consideration when addressing minimum flows. WUA combines habitat quality with area (quantity), and is considered to be more conservative. From a fisheries management perspective, a greater supply of suitable habitat is more important for fish productivity than a small supply of high quality habitat [32], thus WUA was used to arrive at a minimum flow figure.

Taking into account of evaluating 5 species, and it was done through 4 to 7 section analysis is an essential factor when recommending a minimum flow and allocation limit. It requires that ecological "bottom lines" are maintained (Ngaruroro, 2008).

Based on the results of RHYHABSIM and the MALF value which were calculated based on analyzed data of 35 year (1980-2015), recommended minimum flows of the three reaches were proposed (Table 3 ). The recommended minimum flows for reaches $\mathrm{Ma}-\mathrm{Buoi}, \mathrm{Ma}-$ Len and $\mathrm{Ma}$ - Chu are $51 \mathrm{~m}^{3} / \mathrm{s}, 49 \mathrm{~m}^{3} / \mathrm{s}$ and $61 \mathrm{~m}^{3} / \mathrm{s}$, respectively.

It must be stressed that this study only assessed whether or not there is enough habitat available for the river to sustain a healthy ecosystem. Even if the streams are achieving the needed flows for suitable habitat, they still could be underperforming according to the environmental goals set (i.e. not achieving a 'good ecological condition'). Other factors could be influencing the biota, including pollution, predation, invasive species, sedimentation and alteration of stream morphology etc.

It should be recognized that optimal protection of in stream values cannot be achieved when social and economic considerations are accounted for. It is the goal of river management to achieve balance between all in stream values, while maintaining ecosystem health.

Monitoring and follow-up of the data is also important to assure the accuracy of the model results. Continual monitoring of the stream ecosystem is important to assure the accuracy of the model results. Monitoring of the actual flow recommendations, when they are in place, should include visual observations to decide if the flow limits set by the model and the following negotiation are actually meeting the hydromorphological demands of the streams such as covering riffles, providing enough depth in pools etc. The biological component should also be monitored to ensure that the flows are adequate. Monitoring will allow the data input and model output to be assessed and refined as conditions change both in the stream and as a result of management decisions. This will create a more solid basis for ongoing and future 
management decisions.

\section{ACKNOWLEDGMENT}

This research is funded by Ministry of Science and Technology, Vietnam (MOST)) under grant number DTDL.CN-57/15.

\section{REFERENCES}

[1] C. J. Gordon, N.D., T.A. McMahon, Finlayson, B.L., Gippel and and R. J. Nathan, Stream Hydrology: An introduction for ecologists. 2004.

[2] B. Hunt, B., Weir, J. and Clausen, "A stream depletion experiment," Ground Water, vol. 39, no. 2, pp. 283-289, 2001.

[3] K. R. Nyholm, T., Christensen, S., and Rasmussen, "Flow depletion in a small stream caused by ground water abstraction from wells.," Ground Water, vol. 40, no. 4, pp. 425-437, 2002.

[4] P. Thorn and J. Conallin, "RHYHABSIM as a Stream Management Tool: Case Study in the River Kornerup Catchment, Denmark," J. Transdiscipl. Environ. Stud., vol. 5, no. 1, pp. 1-2, 2006.

[5] I. G. Jowett, "Instream fl ow methods: A comparison of approaches: Regulated Rivers," Res. Manag., vol. 13, pp. 115-127, 1997.

[6] K.. Bovee, "A guide to instream habitat analysis using the instream fl ow incremental methodology," Instream Flow Inf. Pap. Fort Collins, U.S. Fish Wildl. Serv., vol. 12, 1982.

[7] T. W. Milhous, R. T., D. L. Wegner, "Users guide to the Physical Habitat Simulation System (PHABSIM).," Instream Flow Inf. Pap. Fort Collins, U.S. Fish Wildl. Serv. (FWS/OBS/81/13)., vol. 11, 1984.

[8] I. G. Jowett, River hydraulic and habitat simulation, RHYHABSIM computer manual., vol. New Zealan. 1989.

[9] A. Bovee, K. D., B. L. Lamb, J. M. Bartholow, C. B. Stalnaker, J. G. Taylor and J. Henriksen, "Stream habitat analysis using the instream flow incremental methodology. U.S.," Geol. Surv. Inf. Technol. Rep. 1998-0004, Fort Collins, Color., 1998.

[10] R. M. Jowett, I., T. Payne, "SEFA-system for environmental flow analysis: software manual version 1.21.," Available: http://sefa.co.nz/. (March 2016)., 2014.

[11] W. Bank, Environmental Assessment (EA) Viet Nam Managing Natural Hazards Project (VN-Haz/WB5), vol. E2993. 2017, p. 18.

[12] J. Hay, "Review of Hawkeees Bay Regional Councilees Instream Habitat Modelling on the Lower Tukituki River.," Prep. Hawke"s Bay Reg. Counc. Cawthron Rep. No. 1542, 2008.
[13] J. Hay, "Instream Flow Assessment for the Lower Ruamahanga River," Prep. Gt. Wellingt. Reg. Counc. Cawthron Rep. No. 1403., 2008.

[14]K. Johnson, "Tukituki River Rhyhabsim and Water Temperature Assessments Tukituki River Rhyhabsim and Water Temperature Assessments Minimum Flow and Water Temperature Assessments," 2013.

[15]B. Clausen and I. G. Jowett, "Guide for the RHYHABSIM program,” pp. 1-14, 1998.

[16]I. G. Jowett, "Survey and analysis of instream habitat," in Computer Manuel, Revised by., NIWA, Hamilton. New Zealand., 1998.

[17]M. and J. F. Kottelat, Handbook of European freshwater fishes. Publications Kottelat, Cornol and Freyhof, Berlin, 2007.

[18]K. H. Alikunhi, "Synopsis of biological data on common carp Cyprinus carpio (Linnaeus), 1758 (Asia and the Far East)," FAO Fish. Synop, vol. 31, no. 2, p. 39, 1966.

[19]I. F. Pravdin, A Guide of Fish Study. Science and Technics Publishing House, Hanoi, 1963.

[20] N. H. D. Nguyen Dinh Vinh, Tran Thi Thuy Ha, Tran Duc Hau, "Morphological and Molecular Identification of species of Catfish Genus Cranoglanis from Lam River, Nghe An, Vietnam," Biol. Forum-An Int. J., vol. 9, no. 2, pp. 37-43, 2017.

[21]H. H. and M. K. Ng, "Cranoglanis henrici (Vaillant, 1893), a valid species of cranoglanidid catfish from Indochina (Teleostei, Cranoglanididae), Zoosystema, vol. 22, no. 4, pp. 847-852, 2000.

[22]T. T. B. Dong Quoc Trinh, "Study on several rproductive biological characteristics of armorhead catfish (Cranoglanis henrici Vaillant, 1893)," J. Fish. Sci. Technol. Nha Trang Univ., vol. 2, pp. 78-82, 2013.

[23]I. J. and H. S. Harrison, "Order Mugiliformes. Mugilidae. Mullets," in FAO species identification guide for fishery purposes. The living marine resources of the Western Central Pacific. Volume 4. Bony fishes part 2 (Mugilidae to Carangidae). FAO, Rome, K. E. C. and V. H. Niem, Ed. 1997, pp. 20692108.

[24]C. M. and D. E. R. Breder, Modes of reproduction in fishes. T.F.H. Publications, Neptune City, New Jersey, 1966.

[25]H. H. Ng, Eleotris fusca. The IUCN Red List of Threatened Species 2012: e.T166077A1109943. 2012.

[26] N. Y. and K. T. Ken Maeda, "Size and age at recruitment and spawning season of sleeper, genus eleotris (Teleostei: Eleotridae) on Okinawa Island. 
Sourthern Japan," Raffles Bul. Zool., vol. Supplement, no. 14, pp. 199-207, 2007.

[27]S. H. M. and M. A. Allen, G.R., Field guide to the freshwater fishes of Australia. Western Australian Museum, Perth, Western Australia., 2002.

[28] R. Pethiyagoda, Freshwater fishes of Sri Lanka. The Wildlife Heritage Trust of Sri Lanka, Colombo., 1991.

[29] W. J. Rainboth, Fishes of the Cambodian Mekong. FAO species identification field guide for fishery purposes. FAO, Rome, 1996.

[30] J. S. Larson, H., Britz, R. \& Sparks, Glossogobius giuris. The IUCN Red List of Threatened Species 2016: e.T166533A19011337. 2016.

[31] Qambrani GR, Soomro AN, Palh ZA, Baloch WA, Tabasum S, "Reproductive Biology of Glossogobius giuris (Hamilton), in Manchar Lake Sindh, Pakistan.," J Aquac Res Dev., vol. 6, p. 392, 2015.

[32] J. H. \& L. K. John W. Hayes, Eric Goodwin, Karen A. Shearer, "Can Weighted Useable Area Predict Flow Requirements of Drift-Feeding Salmonids? Comparison with a Net Rate of Energy Intake Model Incorporating Drift-Flow Processes," Trans. Am. Fish. Soc., vol. 145, no. 3, 2016.

[33]R. Henderson, Relationships between 1-day and 7day MALF in the Horizons Region Relationships between 1-day and 7-day MALF in the Horizons Region Horizons Regional Council ( funded by EnviroLink ( FRST ), project managed by Jon Roygard and, no. October. 2008.

[34] Mike Thompson, "Minimum flow recommendations for the Wellington region. Technical report to support the Proposed Natural Resources Plan," 2015.

[35]Lonelyplanet, "Map of Vietnam." [Online]. Available:

http://www.lonelyplanet.com/maps/asia/vietnam/. 